\title{
Cytarabine Induction Followed by Imatinib Post-Induction Therapy in Patients with Acute Myeloid Leukaemia - Limited Effects in a Case Series
}

\author{
Patrick BRUECK ${ }^{1}$, Oliver G. OTTMANN ${ }^{2}$, Elizabeth RAMOS-LOPEZ ${ }^{3}$, Dieter HOELZER ${ }^{4}$, \\ Angelika BOEHME ${ }^{4}$, Mathias RUMMEL ${ }^{1}$ \\ ${ }^{1}$ University of Giessen, Medical Clinic for Hematology and Medical Oncology, Giessen \\ ${ }^{2}$ University of Frankfurt, Department of Medicine, Hematology and Oncology, University of Frankfurt \\ ${ }^{3}$ University of Frankfurt, Department of Medicine, Endocrinology and Diabetes \\ ${ }^{4}$ Oncologikum, Frankfurt a. M., GERMANY
}

\begin{abstract}
Elderly patients with acute myeloid leukaemia frequently cannot undergo intensive chemotherapy due to comorbidities. We report a retrospective case series of elderly patients with $\mathrm{AML}$ treated with low dose cytarabine induction. Eleven patients with at least $25 \%$ of bone marrow blasts expressing c-kit received Imatinib post-induction therapy, 7 patients entered as controls. Haematologic responses were only slightly better in the Imatinib cohort. No correlation of the response to Imatinib with c-kit expression was noted. Partly due to two early deaths in the control cohort, survival was longer in the Imatinib cohort. Imatinib post-induction therapy after cytarabine induction is feasible in elderly patients with AML not eligible for standard induction but responders to Imatinib have only limited benefit from this low-toxic therapy while no predictive response markers could be found.
\end{abstract}

Keywords: Imatinib mesylate, Acute myeloid leukaemia, Post-induction therapy, Elderly patient

\section{ÖZET}

\section{Akut Myeloid Lösemili Hastalarda İmatinib Post-İndüksiyon Sonrası İmatinib Tedavisi: Vaka Serisinde Kısıtlı Etki}

Akut myeloid lösemili (AML) yaşlı hastalar komorbidite nedeniyle sıklıkla yoğun kemoterapi alamazlar. Bu retrospektif çalışmamızda düşük doz cytarabine indüksiyonu alan yaşı AML'li hastalar değerlendirilmiştir. Kemik iliğindeki blastların en az \%25'i c-kit pozitif olan onbir hastaya indüksiyon sonrası imatinib verilirken 7 hasta kontrol grubu olarak alındı. İmatinib grubunda hematolojik cevap hafifçe daha üstündü ve c-kit ekspresyonu ile imatinib cevabı arasında ilişki saptanmadı. Sağ kalım, imatinib grubunda daha uzundu, bunun kısmen kontrol grubunda iki erken ölüme bağlı olduğu düşünüldü. Buna göre, citarabine indüksiyonundan sonra imatinib, standart kemoterapi alamayan yaşlı AML'li hastalarda uygun görülmektedir. Imatinib'e cevap verenler bu toksisitesi düşük tedaviden çok az yarar gördüler ve cevabı öngörecek herhangi bir belirteç gösterilemedi.

Anahtar Kelimeler: İmatinib mesilat, Akut myeloid lösemi, Post indüksiyon tedavisi, Yaşlı hasta 


\section{INTRODUCTION}

The outcome and survival of patients with acute myeloid leukaemia (AML) depends among other factors on the age of patients at the onset of the disease. 5-year overall survival rates of patients aged 55 years and older have slightly improved from $6 \%$ to $15 \%$ to about $10 \%$ and $25 \%$ as demonstrated in a review by the Eastern Cooperative Oncology Group (ECOG) on the outcome of more than 1400 patients with AML..$^{-3}$ In contrast, the 5-year overall survival rate for patients younger than 60 years is approximately $40 \% .^{4} \mathrm{~A}$ comparison of patients of all adult ages treated in multicenter trials revealed that older age is consistently associated with poorer complete remission rates and a shorter overall survival. ${ }^{5}$ Thus, most patients with AML die of their disease as the median age of patients with AML at diagnosis is approximately 65 to 70 years. ${ }^{6,7}$

The outcome of patients with AML furthermore highly depends on characteristics of the disease as the cytogenetic karyotype, molecular findings, secondary vs. primary disease, response to induction therapy and the intensity of post-remission therapy. ${ }^{8}$ In the population of elderly patients an accumulation of bad risk factors is found and intensity of induction therapy is often limited due to age-related morbidity. Treatment related side effects and infectious complications are generally more severe and thereby limit therapeutic possibilities in induction therapy or post-remission therapy.

Alternative approaches are warranted for elderly patients who are not eligible for standard induction therapy due to underlying morbidities or patient's decision. These therapies might include antibodybased therapies, inhibition of angiogenesis or inhibition of intracellular signals that promote proliferation and/or block differentiation. ${ }^{9-12}$.

AML subtype M2 - associated with $\mathrm{t}(8 ; 21)$ - and AML M4Eo - associated with inv (16) - so called core binding factor AMLs, have a high incidence of expression of early stem cell markers including kit, a receptor tyrosine kinase for the ligand stem cell factor $(\mathrm{SCF})^{13-15}$ and a relevant proportion of these patients harbour a mutated c-kit ${ }^{16}$ with probably activating mutations. ${ }^{17} \mathrm{c}$-kit is expressed with other subtypes of AML in up to $70 \%$ blasts and in vitro SCF leads to an increased proliferation of AML blasts. ${ }^{18-20}$
The first specifically targeted small molecule tyrosine kinase inhibitor Imatinib mesylate (STI571, GleevecTM, GlivecTM) has had a major impact as single agent on the treatment of chronic myelogenous leukaemia $(\mathrm{CML})^{21}$ and Philadelphia chromosome positive $(\mathrm{Ph}+)$ acute lymphoblastic leukaemia (ALL) ${ }^{22}$ It is not only a potent inhibitor of all enzymes containing the Abl kinase domain including c$\mathrm{Abl}$, but also the Abl related Arg, Kit and PDGFRs. ${ }^{23}$

A study by Kindler et $\mathrm{al}^{24}$ with Imatinib as sole therapy in patients with AML reported haematologic responses in a proportion of patients with acceptable toxicities. Based on the preclinical observations and preliminary study results we decided to evaluate on a single case bases the efficacy and toxicity of Imatinib mesylate used as post-induction therapy after a relatively low intensity induction chemotherapy with single cytarabine in patients with AML or advanced myelodysplastic syndrome with need to cytoreductive treatment.

\section{MATERIAL AND METHODS}

Patients and Treatment: In 2005 and 2006, 18 patients of the whole cohort of patients older than 60 years with newly diagnosed or relapsed AML or high-risk MDS (RAEB) were selected for this case series after treatment with a cytarabine induction monochemotherapy. Patients were treated with a cytarabine monotherapy at maximum $100 \mathrm{mg} / \mathrm{m}^{2}$ if they did not qualify for a more intensive induction therapy due to pre-existing or concomitant co-morbidities or a bad performance status at diagnosis. Patients not eligible for cytarabine monotherapy e.g. because of an ECOG performance status III/IV, need for intensive care treatment or uncontrolled infections $[n=24]$ were not included. Furthermore, patients eligible for intensive induction $[n=45]$ were excluded.

Informed consent was obtained from all patients.

All patients evaluated in this analysis were treated in the wards and outpatient department of a single centre and best supportive care was administered following standard procedures.

Eleven of these patients received an Imatinib postinduction therapy beginning with a daily dose of $400 \mathrm{mg}$ on the first or second day after the last do- 
se of cytarabine was administered. All patients of this group accepted to receive this treatment after careful consideration of possible advantages and disadvantages based on scarce available data.

In this context, Imatinib post-induction treatment was offered only to patients with at least $25 \%$ of blast expressing c-kit. No selection was performed on the basis of AML subtype, cytogenetics or prior therapy. Patients with severe hepatic impairment were not offered treatment with Imatinib.

Determination of biological characteristics: Patient bone marrow was evaluated cytologically, histologically, immuno-histochemically and by standardized FACS analysis (Becter-Coulter), metaphase cytogenetics and interphase FiSH.

c-kit expression data was evaluated by FACS after gating the relevant population. If no bone marrow was available for FACS analysis, c-kit expression was analysed by immunohistochemistry.

Data collection: All data was collected from files of the department of Haemato-Oncology of the hospital of the University of Frankfurt and from files of co-operating haemato-oncologists. Beside general and demographic data we evaluated the health status and concomitant diseases of the patients, the type and subtype of AML, cytogenetics and c-kit expression, prior AML therapies, toxicities of our treatment, response to treatment by week four, outcome and subsequent therapies.

Statistical analysis: Statistical analysis is descriptive. T-, $\chi^{2}$ - and $\log$ rank tests were calculated where appropriate. Differences were considered significant if a p value below 0.05 was found. All calculations were done using SPSS version 16.

\section{RESULTS}

We identified 18 patients in our files that fulfilled the above mentioned inclusion criteria for this retrospective analysis. Of these 11 patients were treated with Imatinib mesylate and seven patients served as control cohort. Demographic data is shown in Table 1. No significant differences in demographic bases were observed. Median age of patients

\begin{tabular}{|llll|}
\hline Table 1. Demographic data of patients & \\
\hline Cohort: & $\begin{array}{l}\text { Imatinib } \\
\mathrm{n}=11\end{array}$ & $\begin{array}{l}\text { Control } \\
\mathrm{n}=7\end{array}$ & \\
& & & \\
Gender & $82 \%$ & $43 \%$ & $\mathrm{~ns}$ \\
Male & $18 \%$ & $57 \%$ & \\
Female & 69.6 & 71.3 & $\mathrm{~ns}$ \\
Age (median) & $65.7-75.5$ & $67.5-75.6$ & \\
Quartils & 75 & 70 & $\mathrm{~ns}$ \\
Karnofsky (median) & $70-80$ & $70-70$ & \\
Quartils & & & \\
\hline
\end{tabular}

was 69 years (range 62 to 84 years) in the Imatinib and 71 years (range 63 to 76 years) in the control cohort. Slightly more male patients received Imatinib which was not significant. All patients had a reduced ECOG performance status between I-II and

\begin{tabular}{|c|c|c|c|}
\hline Cohort: & $\begin{array}{l}\text { Imatinib } \\
\mathrm{n}=11\end{array}$ & $\begin{array}{l}\text { Control } \\
n=7\end{array}$ & \\
\hline \multicolumn{4}{|l|}{ Diagnosis } \\
\hline AML & $82 \%$ & $86 \%$ & ns \\
\hline MDS RAEB & $18 \%$ & $14 \%$ & \\
\hline \multicolumn{4}{|l|}{ Subtyp } \\
\hline Primary AML & $82 \%$ & $86 \%$ & $\mathrm{p}=\mathrm{ns}$ \\
\hline Secondary AML & $18 \%$ & $14 \%$ & \\
\hline $\begin{array}{l}\text { Unfavourable } \\
\text { cytogenetics }\end{array}$ & $36 \%$ & $57 \%$ & $\mathrm{p}=\mathrm{ns}$ \\
\hline $\begin{array}{l}\text { c-Kit expression } \\
\text { [Median] }\end{array}$ & 54 & 19 & $p=0.0929$ \\
\hline Quartils & $34-71$ & $10-31$ & \\
\hline \multicolumn{4}{|l|}{ Prior chemotherapy } \\
\hline Yes & $55 \%$ & $29 \%$ & ns \\
\hline Leucocytes & 1,9 & 16,3 & ns \\
\hline Quartils & $1,4-7,2$ & $1.8-26.3$ & \\
\hline$\%$ peripheral blasts & 3 & 16 & ns \\
\hline Quartils & $1-24$ & $2-26$ & \\
\hline
\end{tabular}




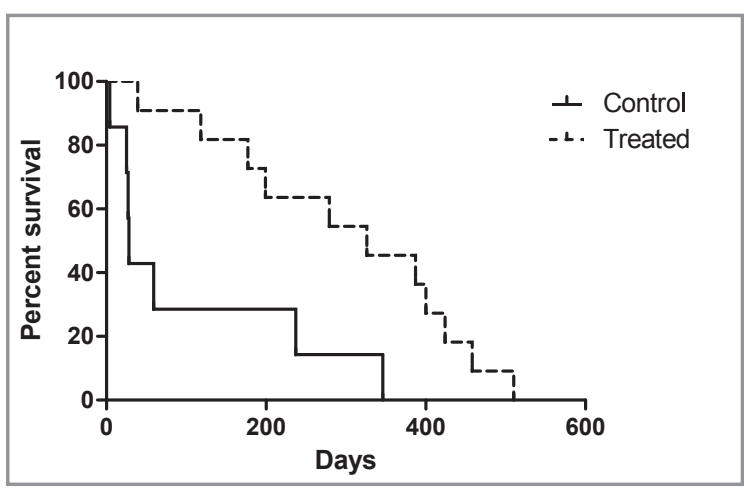

Figure 1. Survival of the patient groups (Control: Cytarabin treated cohort, Treated: Imatinib treatment cohort): A difference in survival of the cohorts is displayed $(p=0.009)$ that is partly - due to four early septic deaths in the control cohort compared to none in the Imatinib cohort

suffered from different pre-existing co-morbidities. Both groups received the same antibiotic, antimycotic and supportive therapy when clinically indicated.

The distribution of patients with primary or secondary AML, with MDS RAEB and with unfavourable cytogenetics was comparable between both groups (Table 2).

A minority of patients (5 of 11 in the Imatinib and 2 of 7 in the control cohort, not significant) had received different chemotherapeutic regimens before receiving cytarabine monotherapy. These regimens ranged from oral hydroxyl urea to standard induction therapy with cytarabine, idarubicin and etoposide phosphate.

Patients in the Imatinib group tended to have a higher c-kit expression on blasts consistent with the decision to offer Imatinib post-induction therapy to patients with at least $25 \%$ of blast expressing c-kit (Table 2). One patient (STI \#2) in the Imatinib group without c-kit expression on blasts was given Imatinib due to the patient's wish. This patient responded temporarily to induction therapy but progressed after only 16 days of Imatinib and died shortly after.

Two patients (AC \#3, AC \#5) in the control cohort eligible for Imatinib treatment refused this kind of therapy due to fear of side effects.

There were no statistically significant differences between the two groups concerning leukocyte or

\begin{tabular}{|c|c|c|c|}
\hline Cohort & $\begin{array}{l}\text { Imatinib } \\
n=11\end{array}$ & $\begin{array}{l}\text { Control } \\
n=7\end{array}$ & \\
\hline $\begin{array}{l}\text { Median total dose } \\
\text { of Cytarabin }\end{array}$ & $865 \mathrm{mg}$ & $871 \mathrm{mg}$ & ns \\
\hline Quartils & $200-975 \mathrm{mg}$ & $200-999 \mathrm{mc}$ & \\
\hline $\begin{array}{l}\text { Median Imatinib } \\
\text { treatment duration }\end{array}$ & 14 days & - & \\
\hline $\min -\max$ & $6-153$ days & - & \\
\hline $\begin{array}{l}\text { Median total dose } \\
\text { of Imatinib }\end{array}$ & $6600 \mathrm{mg}$ & - & \\
\hline Quartil & \multicolumn{3}{|c|}{ 6000-16300 mg- } \\
\hline \multicolumn{4}{|l|}{ Best response (\%) } \\
\hline $\mathrm{CR}$ & 27 & 0 & \\
\hline Blast reduction & 36 & 43 & \\
\hline no change & 9 & 14 & \\
\hline Progressive disease & 27 & 0 & \\
\hline $\begin{array}{c}\text { Death before } \\
\text { evaluation }\end{array}$ & 0 & 43 & \\
\hline $\begin{array}{l}\text { Survival (median } \\
\text { in days) }\end{array}$ & 326 & 28 & $p=0.009$ \\
\hline quartils & $33-356$ & $26-148$ & \\
\hline $\min -\max$ & $39-510$ & $4-346$ & \\
\hline
\end{tabular}

peripheral blast count before the start of cytarabine chemotherapy (Table 2). Furthermore, no difference was seen clinically (ECOG PS) or concerning infections. Elevation of $\mathrm{C}$ reactive protein (CRP) was infrequently seen in both cohorts.

The median total dose of cytarabine administered was $865 \mathrm{mg}(200-975 \mathrm{mg})$ in the Imatinib and 871 $\mathrm{mg}$ (200-999 mg) in the control cohort. Median dose of Imatinib was $6000 \mathrm{mg}$ (6000-16300 mg) and median duration of Imatinib treatment was 14 days (min. 6 to max. 153 days).

There were two early deaths in the control group. It is noteworthy that of these patients one suffered from infectious complications with a clinical response after anti-infectious treatment and showed a falling tendency of the elevated CRP. Still, this patient died on the fifth day of chemotherapeutic treatment after a fatal septic shock with multi-organ 


\begin{tabular}{|c|c|c|c|c|c|}
\hline Patient No. & $\begin{array}{l}\text { c-kit } \\
\text { expression \% }\end{array}$ & $\begin{array}{l}\text { Imatinib treatment } \\
\text { duration (days) }\end{array}$ & $\begin{array}{l}\text { Response } \\
\text { total dose }\end{array}$ & Best response & $\begin{array}{l}\text { Duration } \\
\text { (days) }\end{array}$ \\
\hline STI 1 & 54 & 6 & 5600 & PD & 15 \\
\hline STI 2 & 0 & 13 & 5600 & $\mathrm{PD}$ & 23 \\
\hline STI 3 & 28 & 46 & 19200 & blast reduction & 90 \\
\hline STI 4 & 79 & 153 & 62400 & $\mathrm{CR}$ & 145 \\
\hline STI 5 & 46 & 26 & 13400 & $\mathrm{CR}$ & 140 \\
\hline STI 6 & 15 & 13 & 6400 & blast reduction & 104 \\
\hline STI 7 & 75 & 19 & 12000 & $\mathrm{NC}$ & 94 \\
\hline STI 8 & 67 & 11 & 4800 & blast reduction & 106 \\
\hline STI 9 & 41 & 55 & 21600 & $\mathrm{CR}$ & 60 \\
\hline STI 10 & 93 & 10 & 6600 & blast reduction & 106 \\
\hline STI 11 & 60 & 14 & 6400 & $\mathrm{PD}$ & 30 \\
\hline C 1 & 11,4 & - & - & death in ind. & 2 \\
\hline C 2 & 15 & - & - & blast reduction & 55 \\
\hline C 3 & 26 & - & - & blast reduction & 68 \\
\hline C 4 & n.d. & - & - & blast reduction & 37 \\
\hline C 5 & 47,6 & - & - & NC & 20 \\
\hline C 6 & 6,4 & - & - & death in ind. & 4 \\
\hline C 7 & n.d. & - & - & death in ind. & 12 \\
\hline
\end{tabular}

failure. The other patient died on day four of the treatment from a cardiac arrest of unknown origin. Autopsy led to the diagnosis of septic shock. Two more patients in the control group died from septic complications within four weeks after the initiation of chemotherapeutic treatment.

Concerning overall survival there was a significant difference between the Imatinib treated and the control cohort (median 326 vs. 28 days, $\mathrm{p}=0.009$ ). As there were the described two early deaths in the control cohort the comparison of survival is biased and the clinical impact remains unclear.

Haematological responses were evaluated by week four and the remainder of the patients in the control cohort did worse than the Imatinib cohort as there were complete remissions without full hematologic recovery in the Imatinib cohort whereas there were none in the control cohort (Table 3) after the induction therapy with cytarabine. Responses of all qualities occurred independent of AML subtype or primary or secondary disease (data not shown). It is still noteworthy that about three quarters of the patients in the Imatinib cohort received further chemotherapy (e.g. a second cycle of cytarabine, more aggressive induction chemotherapies or other maintenance therapies) while only one third of the patients in the control cohort did.

There was minor hepatic toxicity in the Imatinib cohort as four patients were found to have a clinically not significant bilirubin elevation. Only one of these four patients developed a diminished liver synthesis and had to stop Imatinib. This patient suffered from a minor hepatic dysfunction as a result of prior anti-rheumatic treatment and developed the 
same adverse reactions after a second onset of Imatinib treatment. No renal toxicity grade II or higher occurred.

Hematologic toxicities were commonly due to cytarabine treatment. Those patients with a complete remission - all in the Imatinib cohort - recovered neutrophil counts to over $500 / \mu$ l between four to six weeks after the first day of cytarabine. Patients with blast reduction only did not recover peripheral blood counts but the neutrophil count of some patients in both cohorts did not fall below 500/ $\mu$ after cytarabine treatment.

Transfusion frequencies were comparable in both cohorts.

15 of 18 patients - except one in the control and two in the Imatinib cohort - suffered from infections. In the control cohort two patients had fever of unknown origin (FUO). These patients had a nadir of neutrophil counts above $500 / \mu 1$. There were four pneumonias in the Imatinib cohort, furthermore two patients with FUO and one patient (with a history of multiple myeloma) with FUO and a clinically suspected generalized Herpes zoster reactivation. As stated above two patients in the control cohort died within days after the initiation of chemotherapeutic treatment from septic complications and two more within four weeks.

No other grade 3/4 side effects were reported.

\section{DISCUSSION}

In this case series we present an evaluation of feasibility and toxicity of an Imatinib post-induction therapy after cytarabine induction chemotherapy in patients with AML who were not eligible for more intense therapy regimens. Within the limitations of a retrospective case series with small patient numbers and heterogenous clinical characteristics and treatment, we observed a limited response to Imatinib in some patients (Table 4). As the Imatinib treatment was started one or two days after the last dose of cytarabine was administered and no bone marrow biopsies performed so early during the treatment sequence, we cannot indicate whether Imatinib induced hematologic remissions by itself or if it maintained remissions induced by the chemotherapy. Those patients who had achieved blast reduction or complete response after induction therapy and were under Imatinib post-induction therapy seemed to benefit as they demonstrated prolonged response durations. This observation is controversial as the response duration did neither depend on the Imatinib dose nor the Imatinib treatment duration what is comparable to results recently published by Heidel et $a 1^{25}$ who used low dose cytarabine and Imatinib as continuous combined therapy for 21 days every 28 days. As our induction therapy was slightly more intense, we observed more and better hematologic responses but comparable results of the post-induction therapy. This translates into a prolonged median survival of 10.6 months in our Imatinib cohort compared to our control cohort or to the above mentioned study. ${ }^{25}$ Patients of the same age group that could be treated with intensive induction chemotherapy within a multicentre clinical trial achieved CR in $64 \%$ and the median remission duration was about 15 months. ${ }^{26}$ The early deaths in our case series and other toxicities are comparable to those reported in other reports. Nevertheless, the survival of our control cohort is biased as all early deaths occurred in this group; therefore the comparison with our control cohort is not substantial in the end.

Even considering the early deaths in the control cohort, there seems to be a difference between both cohorts with respect to response duration. Perhaps, patients with a partial or complete response to induction chemotherapy might benefit from Imatinib as a rather low-toxic post-induction therapy and thereby obtain the possibility to receive further anti-neoplastic therapy.

No correlation of treatment response to c-kit expression was found in our patients. High levels of ckit expression were found in patients with progressive disease as well as in patients with complete remission and prolonged response duration. Patients with a blast reduction were found to have a broad spectrum of c-kit expression. Furthermore, no correlation of c-kit expression with duration of response, Imatinib treatment duration or Imatinib total dose was observed. Therefore, the mechanisms of response to Imatinib in c-kit positive AML remain to be elucidated. It was recently reported that Imatinib has anti-proliferative activity in AML blasts with increased c-kit expression or mutated c-kit and $t(8 ; 21) .{ }^{27}$ However, none of our patients presented with these features. 


\section{CONCLUSION}

The use of Imatinib subsequent to cytarabine monotherapy seems to be a well tolerated option that might induce a prolonged disease control in a subset of patients thus offering the possibility to receive further anti-neoplastic therapy. Cortes et $a{ }^{28}$ had reported only one patient with a transient blast reduction to Imatinib induction therapy in a group of 18 patients with AML or MDS. The use of Imatinib as post-induction therapy could therefore be more reasonable. However, as no predictive markers could be identified and only limited benefit was found in this analysis as well as in other studies, in the end, Imatinib post-induction therapy does not seem to be a valuable option for these patients why we do not further treat our patients with this option.

\section{REFERENCES}

1. Tallman M. Therapy of acute myeloid leukemia. Cancer Control 8: 62-78, 2001.

2. Bennett JM, Young ML, Andersen JW, et al. Longterm survival in acute myeloid leukemia. Cancer 80: 22052209, 1997.

3. Estey E. Acute Myeloid Leukemia and Myelodysplastic Syndromes in Older Patients. J Clin Oncol 25: 190815, 2007.

4. Appelbaum F, Rowe J, Radich J, Dick J. Acute Myeloid Leukemia, Hematology 2001, American Society of Hematology, Education Program Book: 62-86.

5. Hiddemann W, Kern W, Schoch C, et al. Management of acute myeloid leukemia in elderly patients. J Clin Oncol 17: 3569-3576, 1999.

6. Brincker $\mathrm{H}$. Estimate of overall treatment results in acute nonlymphocytic leukemia based on agespecific rates of incidence and of complete remission. Cancer Treat Rep 69: 5-11, 1985.

7. Cartwright RA, Staines A. Acute leukemias. In: Fleming AT, ed. Epidemiology of Hematological Disease, Part I. Baillière's Clin Haematol 5: 1-26, 1992.

8. Lowenberg B, Downing JR, Burnett A. Acute myeloid leukemia. N Engl J Med 341: 1051-1062, 1999.

9. Sekeres MA, Stone RM. The challenge of acute myeloid leukemia in older patients. Curr Opin Oncol 14: 24-30, 2002.

10. Büchner T, Hiddemann W, Berdel W, et al. Acute myeIoid leukemia: treatment over 60. Rev Clin Exp Hematol 6: 46-59, 2002.

11. Hiddemann W, Buchner T. Current status and perspectives of therapy for acute myeloid leukemia. Semin Hematol 38 (3 Suppl 6): 3-9, 2001.
12. Estey EH. How I treat older patients with AML. Blood 96: 1670-1673, 2000.

13. Kita K, Shirakawa S, Kamada N. Cellular characteristics of acute myeloblastic leukemia associated with $\mathrm{t}(8$; 21)(q22; q22). The Japanese Cooperative Group of Leukemia/Lymphoma. Leuk Lymphoma 13: 229-34, 1994.

14. Osato M, Asou N, Okubo T, et al. Myelomonoblastic leukaemia cells carrying the PEBP2beta/MYH11 fusion gene are CD34, c-KIT+ immature cells. $\mathrm{Br} \mathrm{J} H \mathrm{Ha}-$ ematol 97: 656-658, 1997.

15. Escribano L, Ocqueteau M, Almeida J, Orfao A, San Miguel JF. Expression of the c-kit (CD117) molecule in normal and malignant hematopoiesis. Leuk Lymphoma 30: 459-466, 1998.

16. Beghini A, Peterlongo P, Ripamonti CB, et al. C-kit mutations in core binding factor leukemias. Blood 95: 726-727, 2000.

17. Broudy VC, Smith FO, Lin N, et al. Blasts from patients with acute myelogenous leukemia express functional receptors for stem cell factor. Blood 80: 60-67, 1992.

18. Ikeda $\mathrm{H}$, Kanakura $\mathrm{Y}$, Tamaki $\mathrm{T}$, et al. Expression and functional role of the proto-oncogene c-kit in acute myeloblastic leukemia cells. Blood 78: 2962-2968, 1991.

19. Linnekin D. Early signaling pathways activated by c-Kit in hematopoietic cells. Int $\mathrm{J}$ Biochem Cell Biol 31: 1053-1074, 1999.

20. Wang C, Curtis JE, Geissler EN, McCulloch EA, Minden MD. The expression of the proto-oncogene C-kit in the blast cells of acute myeloblastic leukemia. Leukemia 3: 699-702, 1989.

21. Druker BJ, Talpaz M, Resta DJ, et al. Efficacy and safety of a specific inhibitor of the BCR-ABL tyrosine kinase in chronic myeloid leukemia. N Engl J Med 344: 1031-1037, 2001.

22. Ottmann OG, Druker BJ, Sawyers CL, et al. A phase 2 study of imatinib in patients with relapsed or refractory Philadelphia chromosome-positive acute lymphoid leukemias. Blood 100: 1965-1971, 2002.

23. Buchdunger E, Cioffi CL, Law N, et al. Abl proteintyrosine kinase inhibitor STI571 inhibits in vitro signal transduction mediated by c-kit and platelet-derived growth factor receptors. J Pharmacol Exp Ther 295: 139-145, 2000.

24. Kindler T, Breitenbuecher F, Marx A, et al. Efficacy and safety of imatinib in adult patients with c-kit-positive acute myeloid leukemia. Blood 103: 3644-3654, 2004.

25. Heidel F, Cortes J, Rucker FG, et al. Results of a multicenter phase II trial for older patients with c-Kit-positive acute myeloid leukemia (AML) and high-risk myelodysplastic syndrome (HR-MDS) using low-dose AraC and Imatinib. Cancer 109: 907-914 2007

26. Bug G, Koschmieder S, Wiebe S, et al. Priming with Granulocyte Colony-Stimulating Factor (G-CSF) Has No Impact on Treatment Outcome but Impairs Mobilization of Peripheral Blood Stem Cells (PBSC) in El- 
derly Patients with Acute Myeloid Leukemia: Results of a Randomized Oligocenter Trial. American Society of Hematology Congress, San Diego, California, Decembre 4-7, 2004: Abstract 867.

27. Wang YY, Zhou GB, Yin T, et al. AML1-ETO and C-KIT mutation/overexpression in $\mathrm{t}(8 ; 21)$ leukemia: Implication in stepwise leukemogenesis and response to Gleevec. PNAS 102: 1104-1109, 2005.

28. Cortes J, Giles F, O'Brien S, et al. Results of Imatinib Mesylate Therapy in Patients with Refractory or Recurrent Acute Myeloid Leukemia, High-Risk Myelodysplastic Syndrome, and Myeloproliferative Disorders. Cancer 97: 2760-2766, 2003.

\section{Correspondence}

\section{Dr. Med. Patrick Brüeck}

University of Giessen, Department of Medical Clinic for Hematology and Medical Oncology

Klinikstrasse 36

35392 Giessen

GERMANY

Tel: (+49.641) 985-42600

Fax: (+49.641) 985-42609

e-mail: patrick.brueck@innere.med.uni-giessen.de 